\title{
CONSTITUTIONALITY OF PARTY-CIRCLE BILLS
}

\author{
KENNETH C. SEARs*
}

7 HE Sixty-fourth General Assembly of Illinois passed the longdebated party-circle bills applicable in fact only to an amendment of Section 2 of Article XIV of the Illinois constitution. The vote in the Senate was 40 to I; in the House, I27 to 3. Attorney-General Barrett delivered two opinions to Governor Green that these bills were unconstitutional. Despite the fact that the veto message of the Governor, relying in part upon the Attorney-General's opinion, stated that a "copy of his opinion is on file in my office for the inspection of any interested citizen," the Attorney-General's office refused to send to the writer a copy of his opinions. It was claimed that his opinions to the Governor were confidential. At the time this claim was made, a portion of the opinions had already been printed in the Chicago Tribune. ${ }^{x}$ However, a copy of the Attorney-General's opinions was secured through the kindness of John William Chapman, Secretary to Governor Green. The Attorney-General was notified that his opinions would be reviewed by the writer and that it would be assumed that the copy of his opinions received from Mr. Chapman was correct unless the Attorney-General sent a copy from his office. There was no answer to this letter, and here are the opinions of the Attorney-General:

\section{Senate Bill 5 I 4 \\ 64Th GeNeral Assembly}

TO THE GOVERNOR:

At your request, I have examined, as to its form and constitutionality, Senate Bill No. $5 I_{4}$ enacted by the Sixty-fourth General Assembly, being an Act entitled,

An Act in relation to resolutions adopted by political parties with reference to proposed amendments to the Constitution of the State to be submitted prior to January I, I947.

This is a companion Bill to Senate Bill $5 \pi 6$.

This Bill authorizes political parties, prior to January 1 , I947, to adopt a resolution either for or against any proposed amendment to the constitution of the State and forward a certified copy thereof to the Secretary of State. The Secretary of State is authorized to certify such resolution to the county clerk of each county in the State, and the county clerk is authorized in the printing of the ballots to have the proposed amendment printed under the political party appellation.

This Bill is a part of the plan to permit a vote in the party circle to be counted as a

* Professor of Law, University of Chicago.

× Friday, July 27, I945. 
vote for the proposed constitutional amendment, if the political party has by resolution approved the proposed constitutional amendment at its convention.

In my opinion to you on Senate Bill No. $5 \mathrm{I} 6$, as of this date, I held said Bill to be unconstitutional and void. The reasons therein stated apply with equal force to this Bill, which I also hold to be in conflict with Article XIV, Section 2 of the Constitution.

I am therefore returning herewith, Senate Bill No. 5I4 without my approval.

[Signed] GEORGE F. BARRETT

Attorney General

Senate Binl No. 5 I6

TO THE GOVERNOR:

6.4TH GeNerat Assembiy

At your request, I have examined, as to its form and constitutionality, Senate Bill No. 5 I6 enacted by the Sixty-fourth General Assembly, being an Act entitled,

An Act to amend Sections $16-6$ and I7-II of

An Act concerning election, approved

May II, I943, as amended.

This Bill proposes to change the method of voting upon a constitutional amendment submitted to referendum prior to January $I$, I947. It permits the printing of a proposition on the ballot, either for or against the adoption of a constitutional amendment, under the party appellation or title and following the names of the candidates of the political party, in case such political party, at its convention, has adopted a resolution favoring or opposing the amendment. The Bill provides that a vote in the party circle shall be counted as a vote for or against the proposed constitutional amendment, as the case may be, depending upon the resolution of the political party as evidenced by the positive or negative form of the proposition appearing in the party column.

The method prescribed for amending the Illinois Constitution, other than by a constitutional convention, is set forth in Section 2, Article XIV of the Illinois Constitution as follows:

Amendments to this Constitution may be proposed in either House of the General Assembly, and if the same shall be voted for by two-thirds of all the members elected to each of the two houses, such proposed amendments, together with the yeas and nays of each house thereon, shall be entered in full on their respective journals; and said amendments shall be submitted to the electors of this State for adoption or rejection, at the next election of members of the General Assembly, in such manner as may be prescribed by law. The proposed amendments shall be published in full at least three months preceding the election, and if a majority of the electors voting at said election shall vote for the proposed amendments, they shall become a part of this Constitution. But the General Assembly.shall have no power to propose amendments to more than one article of this Constitution at the same session, nor to the same article oftener than once in four years.

In order to determine the validity of Senate Bill 516 , it becomes necessary to ascertain the intention of the framers of the Constitution as disclosed by the language of Section 2, Article XIV. This section of the Constitution requires that a proposed amendment to the Constitution be submitted to the voters for adoption or rejection "in such manner as may be prescribed by law." However, this language is followed by the qualifying proviso that in order for the proposed amendment to become part of our 
basic law a majority of the electors voting at the election must "vote for the proposed amendment."

The usual and customary manner of voting for or against a proposition is a direct vote on the proposition itself-a direct expression of affirmation or negation-a signification of "yes" or "no" in reply to the stated proposition. The object of an election is to obtain and record a correct expression of the will of the-voter. Pierce v. The People, I97 IIl. 432. By means of direct affirmative votes, the people of Illinois have amended the Constitution of 1870 on seven separate and distinct occasions and propositions.

The question of the constitutionality of Senate Bill 516 resolves itself into the question of whether or not the framers of our Constitution could have contemplated the substitution of the indirection proposed in Senate Bill 5 I6 for the time honored and proven custom of direct expression of the will of the voter.

The fundamental and basic rule governing the construction of constitutional provisions, as stated by our Supreme Court in American Breeders' Ass' $n$ v. Fullerton, 325 Ill. 323 , is as follows:

.... The rules of constitutional and statutory construction are the same, (People v. Hutchinson, ${ }_{72}$ Ill. 486 ) and the object in each case is to arrive at the intention expressed by the language used in view of conditions existing at the time of its use.....

The meaning and intention of the language of Section 2 of Article XIV must, therefore, be determined in the light of the conditions existing at the time of its use.

Our present Constitution was drafted and adopted in I87o. A brief resume of the Illinois laws governing the manner of voting, commencing with the admission of Illinois to the Union in 1818 , will aid in ascertaining the intention the Constitutional Convention of 1870 sought to express in Section 2, Article XIV.

Section 28, Article II of the Illinois Constitution of I8r8 provided as follows: "All votes shall be given viva voce until altered by the general assembly."

The first general election law of Illinois was enacted by the Second General Assembly in I82r. This enactment (Laws of Illinois, I821, page 74) provided as follows:

$B e$ it further enacted, That the manner of voting shall be by the elector's approaching the bar in the election room at any time when the poll of the election is open, and addressing the judges of the election in his proper person, and with an audible voice, to be heard by the judges and poll keepers, to mention by name the persons he intends to vote for to fill the different offices which are to be filled at the said election; and the poll keepers shall enter his name and vote accordingly, and then he shall withdraw.

In I829, (Laws of I829, page 54), the provision of the I82I Act above quoted was reenacted with an addition thereto, reading as follows:

.... Provided, that a voter may vote by presenting an open ticket to the judges, containing the names of the persons for whom he votes, and the offices; and the said judges shall read the same to the voter, and the clerks, with the assent of the voter, set the same down in their books, as in other cases.

In 1845 , the foregoing provisions were superseded (Laws of 1845 , page 217 ) by an enactment providing as follows:

Electors shall vote, by first announcing their own names to the judges and clerks of the election, and then the names of the persons for whom they wish to vote; and the clerk shall enter their names and votes accordingly: Provided, That a voter may vote by presenting an open ticket to the judges, containing the names of the persons for whom he votes, and the offices; and the said judges shall read the same to the voter, and the clerks, with the assent of the voter, set the same down in their books, as in other cases. 
It was not until the adoption of the Constitution of 1848 that voting by ballot was made mandatory. Section 2, Article VI of the Constitution of 1848 provided as follows: "All votes shall be given by ballot."

This provision was carried into the Constitution of 1870 as Section 2, Article VII.

The Laws of 1885 (Hurd's Revised Statutes 1885 , page 535) contained the following provisions:

The manner of voting shall be by ballot. The ballot shall be printed or written, or partly printed and partly written, upon plain paper, with the names of each candidate voted for, and the title of the offices. When the ballot is printed, the same shall be printed upon plain paper, in plain type, in straight lines, with a blank space below each name, of a width not less than equal to the width of the line in which the name is printed.

The names of all candidates for which the elector intends to vote shall be written 'or printed upon the same ballot, and the office to which he desires each to be elected shall be designated upon the ballot.

With the advent of the use of tickets in r829, the "party ticket" came into being. However, there were no provisions permitting "party circle" voting and no official ballots provided at public expense. Each voter made up his own "ticket" or used a printed one furnished by the political party.

It was not until the enactment of the Illinois Ballot Act in I8gr that official ballots were furnished at public expense. The Act of $I 89 \mathrm{I}$ incorporated the secrecy of the Australian Ballot system with provisions which, for the first time in Illinois, recognized and permitted "party circle" voting.

The foregoing historical resume demonstrates that at the time of the adoption of the Constitution of 1870 'party circle' voting was unknown in Illinois. It is obvious that the framers of the Constitution of 1870 could not have contemplated that the language used in Section 2 of Article XIV would permit the casting of votes on constitutional amendments by means of the "party circle" device. At the time Section 2 of Article XIV was adopted, the only known method of voting upon a proposition was that by which the voter directly signified his intention upon the precise question through an affirmative or negative vote upon that question.

It appears clear to me that it was the intention of the framers of the Constitution of I87o that an elector, in voting for or against a constitutional amendment, would be required to signify his intention by directly marking his ballot either for or against the proposition.

The provisions of Senate Bill 5 I6 and its companion measure Senate Bill No. $5^{I 4}$ constitute a vicious, craftily conceived scheme designed to confuse and ensnare the electors. These provisions contrive to mislead the voter and to cause him to unwittingly and inadvertently cast a vote he did not intend. These Bills attempt to legalize the perpetration of this fraud and deception. They also seek to substitute the desires of a political party for the considered judgment of the voter on the important issue of changes in our basic law. These Bills strike a foul blow at the freedom and integrity of the ballot. They embody a stratagem which reeks with the savor of machine politics and would substitute the dictates of party conclave for the independent appraisement of the individual elector. The preservation of our constitutional and representative processes of government demands that the franchise of the ballot be kept free from all such artifice and legerdemain. An honest ballot is the symbol of true and good republi- 
can government. Deception and trickery in the elective process has been the tool of the dictatorships.

I have given careful thought, study and consideration to the method of voting which would be authorized by Senate Bills $5 \mathrm{I} 4$ and $5 \mathrm{I} 6$. It is my opinion that they clearly conflict with Section 2, Article XIV of the Illinois Constitution and are, therefore, unconstitutional and void.

For the foregoing reasons, I return Senate Bill No. $5^{\text {I } 6}$ without my approval as to form or constitutionality.

[Signed] GEORGE F. BARRETT

Attorney General

THE FACTS

For the apparent purpose of demonstrating that Illinois voters prior to I87o voted upon constitutional propositions directly (knowingly?) and not indirectly, the Attorney-General purported to make a "brief resume of the Illinois laws governing the manner of voting, commencing with the admission of Illinois to the Union in I818," to "aid in ascertaining the intention the Constitutional Convention of 1870 sought to express in Section 2, Article XIV.".

After quoting the $I 8 \mathrm{r} 8$ constitutional provision requiring viva voce voting, the Attorney-General quotes part of and states that "the first general election law of Mllinois was enacted by the Second General Assembly in I82I." Not so! See "An Act regulating Elections," approved March I, I8Ig. ${ }^{3}$ Failure to quote Section $\mathrm{I} 3$ of this act may have been an oversight. Here it is:

Sect. 13. And it be further enacted, That at all elections hereafter to be held in this state, the electors shall vote by ballot. They shall bring their votes legibly written or printed, on a single piece of paper, with the names at full length, and the offices designated for which such votes are given.--Each ballot shall be folded in such a manner as to conceal from view, the names written thereon, and shall be delivered by the person offering to vote, to one of the judges of the election, who shall put the same into the ballot box, unless rejected as hereinafter provided for.

Section I3, just quoted, seems significant. It seems to conflict with the I8I8 constitutional provision for viva voce voting. It may mean that the first Illinois General Assembly overlooked the constitutional provision. It may mean a dissatisfaction with viva voce voting and an attempt to provide for voting by ballots with at least a measure of secrecy. With ballot voting in existence, political parties could have printed the ballots, gener-

2 The Attorney-General also stated: "The meaning and intention of the language of Section 2 of Article XIV must, therefore, be determined in the light of the conditions existing at the time of its use." The word "use" is curious. The correct word to express the rule is "adoption."

3 Ill. Pub. I. (18Ig) pp. 90-roo. 
ally used, as early as I819, instead of 1829 as asserted by Attorney-General Barrett. Furthermore, it appears to be obvious that under section $\mathrm{r} 3$ of the I8Ig law a constitutional proposition could have been written or printed in the affirmative any place on the ballot, and it would have been a vote for the proposition unless the voter was careful to read his entire ballot and then cancel the proposition if he did not agree with it. That is "indirect" voting, Mr. Barrett. If the Attorney-General saw this I8I9 statute he apparently decided to ignore it and to quote the very different provision in the $\mathrm{I} 82 \mathrm{I}$ law which better suited his purpose. If viva voce voting was strictly enforced under the $182 \mathrm{I}$ law it would appear to have been impossible for an elector to vote on a constitutional proposition without expressing his intention of doing so.

The Attorney-General overlooked, perhaps, another election statute, that of January $3, \mathrm{I} 823 .{ }^{4} \mathrm{It}$ expressly repealed the two preceding acts regulating elections, and it returned to the ballot system of voting set forth in the I8I9 act. The only material change appears to be with reference to an elector who voted in a precinct "where he is not entitled to vote for all the officers to be chosen at such election." Such an elector "shall present to the judges of the election an open ballot, in order that they may be satisfied that such elector has confined his vote to the officers for whom he is entitled to vote." 5 This I823 statute was in opposition to viva voce voting, and again "indirect" voting on constitutional propositions became possible in Illinois.

Apparently the next election act in Illinois is found in the Revised Code of Laws for $1828-29 .{ }^{6}$ The first part of section to of this act is almost the same as the I82I provision for viva voce voting; but the proviso clause states that "a voter may vote by presenting an open ticket to the judges" who are required to "read the same to the voter." Thus, it is clear that under the I8I8 Constitution the General Assembly oscillated beween ballot voting and viva voce voting, and apparently settled upon a compromise that was essentially viva voce voting if the later statutes were strictly enforced. ${ }^{7}$

Section I 5 of the Revised Statutes of 1845 contained the essence of the previous revision of $1829 .{ }^{8}$ Then came the Constitution of 1848 which omitted the $\mathrm{I} 8 \mathrm{I} 8$ provision concerning viva voce voting and provided that "all votes shall be given by ballot." After setting forth these two facts the

4 Ill. Pub. L. (1822-23) pp. 53-68, \$\& 3, I4. s s Ibid., $\$ 3$.

6 Ill. Rev. C. L. (r829) pp. 54-68, particularly \& ro; see also Ill. Rev. Stat. (r833) pp. 243-57. 7 Ill. Rev. Stat. (1845) c. $37, \S 55$.

${ }^{8}$ Set forth in the Attorney-General's opinion, supra. $\quad 9$ Ill. Const. (1848) art. 6, $\S 2$. 
Attorney-General made a leap to the manner of voting provided by the Laws of 1885 . Why did he ignore what was passed between the Constitutions of 1848 and 1870 ? Manifestly, this was the most important period if he really desired to ascertain the meaning of section 2 of Article XIV of the I870 Constitution "in the light of the conditions existing at the time of its use [sic]."

If Mr. Barrett had looked at an act in force February $12, \mathrm{x} 849,{ }^{\mathrm{I0}}$ he would have found that section $I_{5}$ of the Revised Statutes of 1845 , set forth in his opinion, was repealed, and in lieu of it there was enacted the following:

Sec. I5. The method of voting shall be by ballot, which ballot shall be folded by the voter and delivered to one of the judges or board of election, who shall, without unfolding or opening the same in any manner, deposit the said ballot in the said ballot-box; Provided, that no ballot shall be received or counted unless the same is written or printed upon white paper, without any marks or figures thereon, intended to distinguish one ballot from another.

Thus it is clear that viva voce voting was at an end and that secrecy was sought. With a secret ballot in effect, and with political parties long in existence with the privilege of printing party ballots, there was nothing to prevent parties from printing on their ballots only the affirmative of a constitutional proposition. If that occurred then the careless, ignorant, or unwary voter using such a ballot uncancelled would vote for the constitutional proposition even though he was unaware of that fact. That is what our Attorney-General designates as "indirect" voting. It was indulged in before $189 \mathrm{x}$ and Mr. Barrett's specious distinction between party-ticket voting and party-circle voting will not fool any reasonably intelligent individual who cares to read the history of voting in this and other states. There was no party-circle voting before $189 \mathrm{I}$ because parties with their party tickets needed no party-circle. For example, a particular group within the Democratic party in I880 placed the Republican candidates for Governor and Secretary of State on its party ticket. Therefore, the Australian ballot law of $\mathrm{I} 8 \mathrm{gx}$ was a reform law that more strictly regulated ballots, despite the concession that political parties could have their party circles. ${ }^{\text {II }}$

ro IIl. Pub. L. (1849) p. 74, § I5.

xI Ill. Pub. L. (1822-23) p. I80; Ill. Pub. L. (185I) p. I07; Ill. Pub. L. (1869) p. 96; Sears, Horse and Buggy Government, Chicago Sunday Times, p. 6M (April 30, I939); Laughlin, A Study in Constitutional Rigidity, I., ro Univ. Chi. L. Rev. I42 (I943); Sears and Laughlin, A Study in Constitutional Rigidity, II., II Univ. Chi. L. Rev. 374 (r944); Bogart and Mathews, Centennial History of Illinois 199 . 
The method of voting provided by the law of 1849 appears to have remained effective until the Constitution of 1870 was adopted. ${ }^{12}$

\section{THE IAW}

A legal opinion that an act of a legislature is unconstitutional is almost always supported by authority. But Attorney-General Barrett cites only two cases and these are cited only for general propositions that are acceptable. The cases cited are not pertinent to the solution of the question of the constitutionality of the party-circle bills. It is hardly possible that there is any case law in Illinois on this question because Illinois has never had a party-circle law for voting on constitutional propositions. Thus, the opinion of the Attorney-General is not supported by a single cited decision.

Of far greater importance, Barrett's opinion is contrary to Ohio and Nebraska cases which decided that party-circle statutes were constitutional.

Section I, Article XVI of the Ohio Constitution of $185 \mathrm{I}$ provided: ${ }^{13}$

Either branch of the General Assembly may propose amendments to this constitution; and, if the same shall be agreed to, by three-fifths of the members elected to each House, such proposed amendments shall be entered on the journals, with the yeas and nays, and shall be published in at least one newspaper in each county of the State, where a newspaper is published, for six months preceding the next election for Senators and Representatives, at which time the same shall be submitted to the electors, for their approval or rejection; and if a majority of the electors, voting at such election, shall adopt such amendments, the same shall become a part of the Constitution. When more than one amendment shall be submitted at the same time, they shall be so submitted, as to enable the electors to vote on each amendment separately.

In 1902 the Ohio legislature passed a party-circle bill applicable to constitutional amendments. ${ }^{\mathrm{x}}$ In a test case, the Ohio Supreme Court, without dissent, sustained the constitutionality of this party-circle law. ${ }^{\mathrm{Ts}}$ The problem for decision was set forth in this manner:

The relator sets forth in his petition that, by certain joint resolutions passed by the general assembly of the state of Ohio, it was agreed to submit to the electors of the state of Ohio, on the first Tuesday after the first Monday of November, I903, certain propositions to amend the constitution of the state of Ohio, which propositions are described in the petition. It is also alleged that under the act of the general assembly, passed May 2, I902, entitled "An act to provide for the manner of submission of con-

${ }^{12}$ I Ill. St. 18 I8-1869 (Gross) c. $37, \S$ I6.

${ }_{3}$ Ohio Stat. ( 1853$)$ p. 80.

${ }^{4}$ Ohio Acts (1902) p. 352. The significant sections of this law are set forth in Sears and Laughlin, op. cit. supra, note Ir, at 399 .

${ }^{15}$ State ex rel. Sheets v. Laylin, 69 Ohio St. I, 68 N.E. 574 (1903). 
stitutional amendments and other questions to a vote of the people" (95 O.L., 352), the republican and democratic parties of the state of Ohio, in convention assembled, took action in favor of the adoption of certain of such constitutional amendments, and also against the adoption of certain other constitutional amendments, and certified their action to the secretary of state in the manner provided for certifying nominations for state offices; and that the defendant, as secretary of state, pursuant to said act, is preparing, and is about to print such action of said parties, so certified to him, upon the official ballot for use at the election to be held on the first Tuesday after the first Monday of November, A.D. I903, as part of the party ticket of each of said parties; and in all other respects in the preparation of such ballot and the placing of such constitutional amendments thereon, is complying with the requirements of the said act of May 2, 1902; and the relator alleges that the exercise by the defendant of any of the franchises, privileges, rights or powers sought to be conferred by said act is in contravention of the constitution of the state of Ohio, and prays that he be compelled to answer by what warrant or rights he claims to act in the preparation or arrangement of such ballot in the form aforesaid, and by what warrant or right he is about to have printed upon such ballot the action in favor of or against the adoption of such constitutional amendments by the parties aforesaid, and that upon the hearing hereof he be ousted from the rights, franchises and privileges so claimed. The defendant demurred to the petition on the ground that it did not state facts sufficient to constitute a cause of action. ${ }^{16}$

The solution of the problem did not appear to trouble the court, which rendered a brief opinion. The significant part of this opinion is quoted. Observe that the Ohio Supreme Court thought that a party-circle vote was an express method of voting on constitutional amendments. ${ }^{17}$

It was not the design or intention of the constitution to put a premium on ignorance or indifferentism at the same time that it is the duty of every citizen to inform himself and to vote upon every matter submitted to a vote of the people. Out of the proposition that a constitution adopted by the people can be amended only by a majority of the people, it naturally follows that of all the people voting at an election when an amendment to the constitution is submitted, only those should be counted for the amendment who expressly so vote, and this is the whole scope of article $I 6$, section $I$, of the constitution of Ohio.

The act of the general assembly entitled "An act to provide for the manner of submission of constitutional amendments and other questions to a vote of the people," passed May 2, 1902 (95 O.L., 352), enables the elector to vote with or against his party, on each or all of the amendments, or to vote separately upon each and every proposed amendment, or to not vote at all if he so desires. So far as we have been able.to discover the act is not in any respect in conflict with the constitution, and not irreconcilably in conflict with the joint resolutions adopted by the general assembly submitting propositions to amend the constitution.

Demurrer to petition sustained and petition dismissed..8

${ }^{16}$ Ibid., at 2 and 575 .

${ }^{17}$ Further information concerning' Ohio is set forth in Sears and Laughlin, op. cit. supra, note II, at 389 .

${ }^{18}$ State ex rel. Sheets v. Laylin, 69 Ohio St. I, I4, 68 N.E. 574, 575 (I903). 
Perhaps the idea of the court was more tersely expressed by AttorneyGeneral Sheets who appeared for relator. He said: "The act cannot be considered as an unreasonable infringement on the right of a voter to express his will untrammeled, for if it were, it would necessarily follow that the whole Australian method of voting would be an infringement on the right of suffrage, hence unconstitutional."

Section I of Article XVII of the Nebraska constitution of 1875 provided:20

Either branch of the legislature may propose amendments to this constitution, and if the same be agreed to by three-fifths of the members elected to each house, such proposed amendments shall be entered on the journals, with the yeas and nays, and published at least once each week in at least one newspaper in each county, where a newspaper is published, for three months immediately preceding the next election of senators and representatives, at which election the same shall be submitted to the electors for approval or rejection, and if a majority of the electors voting at such election adopt such amendments, the same shall become a part of this constitition. When more than one amendment is submitted at the same election, they shall be so submitted as to enable the electors to vote on each amendment separately.

By a number of amendments of the existing statute governing elections, the Nebraska legislature adopted a party-circle law as to constitutional amendments. ${ }^{2 x}$ An amendment adopted in 1906 with the assistance of this party-circle law was promptly challenged. But the Nebraska Supreme Court in a unanimous opinion decided that the amendment was valid. ${ }^{22}$ The first two points considered by the court are of no importance here, but the third question was this: "Is there authority of law for counting for the constitutional amendment the straight party votes of the republican, democratic, and people's independent party?" In answering this question affirmatively, the court seemed at a loss to understand why any other answer could be seriously contemplated. The only problem considered was whether there was a violation of the not uncommon provision that: "When more than one amendment is submitted at the same election they shall be so submitted as to enable the electors to vote on each amendment separately." The court's solution of the problem was this:

The objection that the provisions of our statute above quoted are not such "as to enable the electors to vote on each amendment separately," when several amendments

I9 State ex rel. Sheets v. Laylin, 69 Ohio St. r, 3 (Igo3).

${ }^{20} \mathrm{Neb}$. Ann. Stat. (Cobbey's, IgII) p. I55. It will be observed that this section of the Nebraska constitution is very similar to the Ohio constitutional provision set forth above.

${ }^{2 x}$ Detailed information is set forth in State ex rel. Thompson v. Winnett, $78 \mathrm{Neb} .379$, Iro N.W. III3 (r907), and Sears and Laughlin op. cit. supra, note II, at 383 .

${ }_{22}$ State ex rel. Thompson v. Winnett, 78 Neb. 379, IIO N.W. IIr3 (IgO7) 
are submitted, appears to be without foundation. The voter may vote a straight party ticket if he desires, but he is not compelled to do so. He may vote a straight party ticket in general and make such exceptions as he desires either as to the individual candidates or as to any proposed constitutional amendment. The directions for so doing in the statute appear to be practicable and without uncertainty. It is not the duty of the court to suggest methods of submitting constitutional amendments to the vote of the people. The duty of devising and applying such methods is devolved upon the legislature, and, unless the method adopted by the legislature is manifestly a violation of the constitution, and unless it clearly appears that the method adopted by the legislature will not make it practicable for the voters to express their judgment as to each amendment proposed, the courts are not at liberty to disregard the will of the legislature. A similar method of submitting constitutional amendments has been upheld by the Supreme court of Ohio.23

The Ohio and Nebraska cases, as far as is known are the only ones that are strictly in point on the constitutionality of the party-circle bills passed by the Illinois General Assembly last June. Both of them are clearly contrary to the conclusion reached by Attorney-General Barrett. $\mathrm{He}$ ignored them, and it would seem that he did this because he could not satisfactorily differentiate them. Section 2 of Article XIV ${ }^{24}$ of the Illinois Constitution is similar to the comparable provisions in the Ohio and Nebraska constitutions already quoted except that: (I) Illinois has no express provision requiring the separate submission of each amendment; (2) Illinois has a provision limiting the General Assembly to amendments to a single article at each session; and (3) Illinois, contrary to Ohio and $\mathrm{Ne}$ braska, expressly provides that amendments "shall be submitted to the electors of this State for adoption or rejection .... in such manner as may be prescribed by law." The party-circle bills were enacted in pursuance of this power to prescribe the manner of submitting amendments to the electors. There is no express limitation in section 2 of Article XIV on the "manner." But Attorney-General Barrett needed an implied limitation on this grant of power, and he proceeded to find one. He looked at the following sentence in section 2 which provides that amendments shall be-

23 Tbid., at 394-95 and III8.

24 "Sec. 2. Amendments to this Constitution may be proposed in either House of the General Assembly, and if the same shall be voted for by two-thirds of all the members elected to each of the two houses, such proposed amendments, together with the yeas and nays of each house thereon, shall be entered in full on their respective journals, and said amendments shall be submitted to the electors of this State for adoption or rejection, at the next election of members of the General Assembly, in such manner as may be prescribed by law. The proposed amendments shall be published in full at least three months preceding the election, and if a majority of the electors voting at said election shall vote for the proposed amendments, they shall become a part of this Constitution. But the General Assembly shall have no power to propose amendments to more than one article of this Constitution at the same session, nor to the same article oftener than once in four years." 
come a part of the Illinois Constitution "if a majority of the electors voting at said election shall vote for the proposed amendments." This last sentence was stated by the Attorney-General to be a "qualifying proviso" upon the previous provision that amendments are to be submitted "in such manner as may be prescribed by law." But there is no "proviso" in the sense in which that word is used by legislative draftsmen. The sentence in section 2 concerning the number of votes required is just one of the several sentences in this section.

However, suppose that it is admitted that the sentence concerning the necessary votes is a "qualifying proviso" of the preceding sentence concerning the manner of submission. What of it? We are in a blind alley, unless it is further assumed that the word "vote" means that an elector must vote according to one of the methods of voting on constitutional propositions that have been prescribed by law in Illinois since the passage of the Australian Ballot Act in r89r. The Attorney-General was again equal to the occasion, and he made the assumption. In order to support his position he made a tricky misstatement of the historical facts. Here it is: "By means of direct affirmative votes, the people of Illinois have amended the Constitution of $x 870$ on seven separate and distinct occasions and propositions." Here are the facts. Of the seven amendments which have been adopted, five were adopted before the passage of the r8gr act. ${ }^{25}$ All five were adopted during the time that the electors could only use unofficial ballots, prepared in the main by various party organizations. If these organizations favored an amendment and printed only the affirmative of the issue on their ballots the voters using them voted for the amendment, regardless of their knowledge and intention, unless they were careful to scratch the affirmative statement. This is common knowledge and there is no reason to think that George F. Barrett is ignorant of it. Therein lies the deception. There is sufficient evidence of this practice of voting for constitutional propositions by merely using party tickets. ${ }^{26}$ This is what the Attorney-General calls indirect voting, the type of voting, says he, that is prohibited by section 2 of Article XIV of the Illinois Constitution. The result of his reasoning would be that the first five amendments to the Illinois Constitution of $x 870$ are invalid because they were adopted by an unconstitutional method of voting.

An additional deception is occasioned by treating the adoption of the last two of the seven Illinois amendments as presenting the same legal problem as the adoption of the first five. There can be no dispute that the

${ }^{25}$ Laughlin, op. cit. supra, note $\mathrm{I}$, at $\times 50$.

${ }^{26}$ Sears, op. cit. supra, note II; Bogart and Mathews, op. cit. supra, note II. 
last two were adopted in I904 and Ig08 under the "little" or separate ballot method of voting. ${ }^{27}$ There, indeed, the voter was in effect a negative voter unless he took his little ballot and made a cross $[\mathrm{x}]$ in the proper place on this ballot. Under this method there could be no indirect affirmative votes, but there were many automatic negative votes, including all voters who could not be bothered with a mere constitutional amendment and also those who overlooked voting upon the little ballot. But this sort of indirect voting is constitutional even if it is a public curse.

- After making his inaccurate and deceptive historical statement the Attorney-General stated that the question of the constitutionality of the party-circle bills "resolves itself into the question of whether or not the framers of our Constitution could have contemplated the substitution of the indirection proposed in Senate Bill $5^{1} 6$ for the time honored and proven custom of direct expression of the will of the voter." The answer given by the Attorney-General follows:

The foregoing historical resume demonstrates that at the time of the adoption of the Constitution of I870 "party circle" voting was unknown in Illinois. It is obvious that the framers of the Constitution of $\mathrm{x} 870$ could not have contemplated that the language used in Section 2 of Article XIV would permit the casting of votes on constitutional amendments by means of the "party circle" device. At the time Section 2 of Article XIV was adopted, the only known method of voting upon a proposition was that by which the voter directly signified his intention upon the precise question through an affirmative or negative vote upon that question.

It appears clear to me that it was the intention of the framers of the Constitution of I870 that an elector, in voting for or against a constitutional amendment, would be required to signify his intention by directly marking his ballot either for or against the proposition.

It is submitted that the first two sentences in this answer are deceptive. Who has said that the party-circle method of voting existed in Illinois in $\mathrm{r} 87 \mathrm{O}$ ? What has been stated is that at the time the present Illinois Constitution was adopted the method of voting was by unofficial ballots; that most ballots were prepared by party organizations; that party organizations could and did favor constitutional propositions and could and did print only the affirmative of the propositions on their ballots, when they so desired; that this was an effective method of adopting constitutional propositions by use of unofficial party ballots; that the party-circle bills are consistent with this historical tradition; and that if the fathers of the constitution knew, used, and approved of the party-ticket method of voting on constitutional propositions there is no good constitutional reason why present-day electors cannot use the party-circle method when this

${ }_{27}$ Laughlin, op. cit, supra, note II, at I5O. 
method is less drastic and better regulated than the party-ticket method was in 1870 . Nebraska and Ohio used it to get out of a constitutional bog. Why can't Illinois do the same?

The third sentence in the Attorney-General's answer is utterly false. Nothing is cited in its support and it is contrary to the common information of those who know the history of voting in Illinois. The fourth and last sentence is based on the third.

The Attorney-General failed to mention another item concerning voting in Illinois in 1870 . The ballot that was used in voting upon the Illinois.Constitution of 1870 is set forth in section Io of the schedule of that document. Here it is:

Section so. At the said election the ballots shall be in the following form:

\section{NEW CONSTITUTION TICKET}

For all the propositions on this ticket which are not cancelled with ink or pencil; and against all propositions which are so cancelled.

For the New Constitution.

For the sections relating to railroads in the article entitled "Corporations."

For the article entitled "Counties."

For the article entitled "Warehouses."

For a three-fifths vote to remove County Seats.

For the section relating to the Illinois Central Railroad.

For the section relating to Minority Representation.

For the section relating to Municipal Subscriptions to Railroads or Private Corporations.

For the section relating to the Canal.

Each of said tickets shall be counted as a vote cast for each proposition thereon not cancelled with ink or pencil, and against each proposition so cancelled, and returns thereof shall be made accordingly by the judges of election.

Observe the obvious fact that this ballot was designed to make it easy to vote "For the New Constitution" and the eight separately submitted propositions and not so easy to vote against them. Observe also that if a voter came to the polls in July, r87o, with the intention of voting "For the New Constitution" and accordingly proceeded to drop the prescribed ballot in the ballot box without making any marks on his ballot he would have been counted as voting for the eight additional propositions even though he had never read or heard about them and even though he had no intention concerning them. Even if he had come to the polls with the intention of voting against the new constitution or against one or more of the eight additional propositions he would have voted for these propositions if he had misunderstood the meaning of the ballot and dropped it in the ballot box without change. Even if he had correctly understood his 
ballt but had failed through oversight or other error to cancel the propositions that he did not favor, still he would have voted for them. And yet our Attorney-General has the effrontery to assert: "At the time Section 2 of Article XIV was adopted, the only known method of voting upon a proposition was that by which the voter directly signified his intention upon the precise question through an affirmative or negative vote upon that question." If George Barrett is not careful, he will be declaring sections Io to I2 inclusive of the schedule to be invalid because they conflict with Article XIV and thus that Illinois is controlled by its 1848 Constitution because the 1870 Constitution is invalid since it was adopted through an unconstitutional method of voting.

However, there is an Alabama decision which sustains the method of voting that was used to adopt the Illinois Constitution of $1870 .^{28}$ At that time the Alabama constitution provided for the submission of constitutional amendments "at the next general election which shall be held for representatives .... and, if it shall thereupon appear that a majority of all the qualified electors of the state, who voted at said election, voted in favor of the proposed amendments, said amendments shall be valid."'29 The similarity of these provisions to provisions in the Illinois Constitution is obvious. The Alabama General Assembly of $1896-97$ submitted to the voters a taxation amendment applicable to the city of Birmingham alone. ${ }^{30}$ The act submitting the amendment provided that it should be submitted at the general election to be held in August, 1898 . It was also provided that the official ballot to be used at this election should have printed upon it these words: "For Birmingham Amendment." No other words concerning this proposition were to appear on the ballot. The act of submission also provided that the specified words were to be printed "after the names of candidates for state offices and before the names of candidates for county offices." Thus it would appear that the amendment proposition consisting of three words was printed in the middle of the ballot. That this was an obscure if not a deceptive place to print the proposition can hardly be doubted. ${ }^{3 x}$

The Alabama act of submission prescribed the manner of voting on the Birmingham amendment:

Any elector desiring to vote for said amendment shall leave said words intact upon his ballot, and any elector desiring to vote against said amendment shall evidence his

${ }^{28}$ May \& Thomas Hardware Co. v. Mayor and Aldermen of Birmingham, I23 Ala. 306, 26 So. 537 (1898).

${ }^{29}$ Ala. Const. ( 1875$)$ art. $17, \S \mathrm{r}$.

30 Ala. Acts (1896-97) p. r202.

${ }^{3 x}$ Compare the voting upon the Illinois amendments in 1892 , I894, and 1896 , when they were printed beneath the names of the candidates. Laughlin, op. cit. supra, note II, at I5I. 
intention to so vote by erasing or striking out said words with pen or pencil. The leaving of said words upon the ballot shall be taken as a favorable vote, and the erasure or striking out of said words as aforesaid shall be taken as an adverse vote, upon said amendment.

The Birmingham amendment was adopted, and it would appear that it would have taken something in the nature of a political revolution to have prevented its adoption, in view of the drastic method of voting that was prescribed. But this is the method of voting that was provided for the adoption of the Illinois Constitution of 1870 . The only material difference is that the Illinois election was a special one, even though some judges were elected at the same time, ${ }^{32}$ while the Alabama election was a general election. An attack upon the Birmingham amendment was supported by an able argument. ${ }^{33}$ It was asserted by counsel that the amendment was invalid because the prescribed method of voting upon it violated two sections of the Alabama constitution. The main argument was that that part of the Alabama constitution quoted, supra, required positive, affirmative action by the electors to manifest an intention to vote in favor of the amendment, while the statute, on the contrary, required no affirmative action to manifest an intention to vote in favor of the amendment but positive, affirmative action to manifest an intention to vote against the amendment. As a result, it was argued, the Birmingham amendment was declared to have been adopted even though it was impossible to know whether a majority of the electors who voted at the election, had the intention to vote for it, or whether they even knew of its existence. Despite this argument the Alabama Supreme Court in a unanimous decision held that the Birmingham amendment had been validly adopted. The court asserted that "every voter is presumed to know what is on any ballot he deposits as an expression of his will." Armed with this presumption, which the court appears to have thought of as conclusive, it was not difficult for the court to conclude that the Alabama voters who failed to erase or strike out "For Birmingham Amendment" in legal contemplation affirmatively expressed their favor for the amendment.

The second objection to the validity of the Birmingham amendment was that the statute violated section I of Article VIII of the Alabama constitution which guaranteed to every citizen, who possessed the specified qualifications of a voter, the right to vote at every election. More specifically, the argument was that: "The statute takes away from the elector

32 Ill. Const., schedule $\$ 7$.

${ }_{33}$ May \& Thomas Hardware Co. v. Mayor and Aldermen of Birmingham, 123 Ala. 306, 3 ro (1898). 
his right, recognized by the Constitution to refrain from voting on the amendment and at the same time to vote for the State and county offices to be filled at the election." The court's answer to this argument follows: ${ }^{34}$

This position takes no account of the consideration that under any possible form of submitting a proposed amendment to the people every elector who votes for a State or county office at the election must through the operation of the Constitution itself in effect vote for or against the amendment. Article XVII, section I provides, as we have seen, that an amendment must receive "a majority of all the qualified electors of the State who vote at" the general election to which it is submitted, a majority, not of those who vote on the amendment, but of those who deposit ballots for any purpose. Hence it is that if an elector votes for a State or county office, he necessarily votes on the amendment, for though his ballot contain no reference to the amendment he is counted against it. So that by the terms of the Constitution itself he is deprived of the right to refrain from voting on an amendment if he votes for any State or county office; and the statute cannot be violative of the Constitution for having this same operation and effect. The most that can be said of the statute in this connection is that under it it is easier for the elector to vote for the amendment than against it, in that to vote against it he is put to the physical exertion of drawing a pen or pencil through the words "For Birmingham amendment," and he may vote for it without doing this; and of this it is sufficient to say that such regulations have been several times, and we think correctly held valid.

A New Jersey case ${ }^{35}$ is also of interest. In the first place it is stated that New Jersey four times in its history has made use of the Alabama-Illinois type of ballot on constitutional propositions. In the second place the New Jersey Supreme Court unanimously rejected an argument that such a ballot was unconstitutional because it did not give the voter an opportunity to vote on one of three constitutional amendments and to refuse to vote on the other two or on one of them. As in Illinois, if a New Jersey voter voted at all in the special election he could not avoid voting for or against all three amendments. Contrary to Attorney-General Barrett's dictum, it was not necessary that the "voter directly signif[y] his intention upon the precise question through an affirmative or negative vote upon that question." If the New Jersey voter voted directly upon the first amendment and made no mark to signify his intention as to the other two, nevertheless he would have cast affirmative votes for the latter two propositions.

In the New Jersey Court of Errors and Appeals, however, the decision on this latter point is somewhat confused and divided. The judgment of the Supreme Court was affirmed unanimously, but there was some differ-

34 Ibid., at 324-25.

35 Bott v. Wurtz, Secretary of State, 63 N.J.L. 289, 43 Atl. 744, 88I (I899), affirming 6r N.J.L. I63, 38 Atl. rog9 ( 1897 ) and 62 N.J.L. I07, 40 Atl. 740 (1898). 
ence of opinion and the exact division of the court is not made clear. ${ }^{36}$ Here is the significant language of the latter court:

The other objection urged by the prosecutors is that the act providing for the submission of the amendments to the people prescribed such a method of voting-that while every voter was at liberty to vote for any amendment and against the others, or vice versa, no elector could vote on any amendment unless he voted on all. This, it is contended, was not submitting the amendments "in such manner and form that the people might vote for or against each amendment separately and distinctly."

Assuming the effect of the statute to be as alleged, it is not clear that it would antagonize the constitution. There is, indeed, a sense in which, under such a law, the people could not vote for or against each amendment separately and distinctly-that is, they would be required to determine how they would vote on any amendment in conjunction with a determination as to how they would vote on each of the others. But in another and an important sense they could vote for or against each separately and distinctly - that is, a determination to vote for or against any one left them entirely free to determine how they would vote on each of the others.

In which of these senses the constitution should be taken is doubtful, and the members of the court are not as one about it; and, under the established rule that courts will not condemn a statute as unconstitutional unless its repugnancy to the constitution be clear, we would hesitate to adjudge this enactment invalid.

But there is another reason to withhold us from such a judgment. Under the statute the election proceeded throughout the state without objection on the part of any person, and, so far as appears, every qualified voter who desired to exercise his franchise has done so in a mode satisfactory to himself, without seeking to vote on some of the amendments while refraining from voting on the rest. So that no right has been denied; no will competent to influence the election has been thwarted, and the discrepancy between the statute and the constitution, if there be any, has proved to be of no practical moment. Under these circumstances we think the same public policy which permitted the prosecutors to present the supposed public grievances now requires us to declare that this is not such a grievance, and the theoretical objection has been waived. ${ }^{37}$

\section{CONCLUSIONS}

Even though Attorney-General Barrett's opinion is based upon a false premise of fact and is contrary to all the known law there is on the subject, there is nothing that will prevent the Illinois Supreme Court from agreeing with him if the question ever comes before that court. There is nothing in the law that is less predictable than constitutional law. Notions about governmental policy, party bias, political ambition, various sorts of selfishness-all of these are potent in the writing of opinions on constitutional law.

One cannot forget George Barrett's obvious political ambitions and his harmonious relation with the Tribune Tower, the most powerful, persist-

${ }^{36}$ See the discussion of these cases in Dodd, The Revision and Amendment of State Constitutions $185^{-209}$ (Igro).

37 Bott v. Wurtz, Secretary of State, 63 N.J.L. 289, 30I-302, 43 Atl. 744, 748-49 (1899). 
ent, demagogic, and unyielding foe of constitutional reform in Illinois. This is sufficient to explain why the Attorney-General devoted a paragraph in his opinion to a "stump" speech denouncing the party-circle bills as a "vicious, craftily conceived scheme" which "strike(s) a foul blow at the freedom and integrity of the ballot," et cetera. Then he elevated himself to glory by pretending to protect an honest ballot against machine politics. Quite a blast against a Republican Senate which passed the bills 40 to I, and a Republican House which passed them 127 to 3 over the intense opposition of Governor Green, who first approved the bills and requested their introduction in the Senate, and then attempted to defeat them in the House after the Chicago Tribune condemned them in an editorial. Also it was quite a blast against many organizations which supported the party-circle bills, such as the Illinois Agricultural Association, Illinois Educational Association, Illinois School Boards Association, City Club of Chicago, and the Chicago Bar Association. As against the endorsement of such associations George Barrett's bombast will be passed over by most persons as another ridiculous episode in the long struggle against selfish reactionaries to secure constitutional reform in Illinois. 